\title{
Survey of Japanese Beetle Management Practices in Michigan Highbush Blueberry Production
}

\author{
Zsofia Szendrei ${ }^{1}$ and Rufus Isaacs ${ }^{2}$
}

Additional Index wORds. Popillia japonica, Vaccinium corymbosum, cultivation, pest, economic impact, grower survey

SumMaRY. Michigan higbush blueberry (Vaccinium corymbosum) growers were surveyed during Winter 2003 to gather information on the extent of the pest status of japanese beetle (Popillia japonica, Coleoptera: Scarabaeidae) within this crop, and their responses to this pest management challenge. The survey was mailed to 215 highbush blueberry farms in southwestern, central, and southeastern Michigan. Ninety-nine surveys were completed and returned. Our results revealed that this pest was of concern to the majority of growers who returned the survey $(84 \%)$, causing average additional costs of $\$ 72 /$ acre. Increased insecticide use was the major cause of the economic loss due to this pest, and the main methods for controlling japanese beetle were insecticides and clean cultivation. More farms had permanent sod coverage than clean cultivation in individual fields. The acreage of clean-cultivated farms was higher because larger farms tend to have clean cultivation. Japanese beetle has driven changes in row-middle management, indicated by growers who have switched to clean cultivation recently. Fifty percent of growers considered the changes they implemented to control japanese beetle to be effective, and most growers were not planning any further changes to their pest management programs to address this pest. Many growers were willing to try new cover crops if they are shown to be effective against japanese beetle.

$\mathrm{M}$ ichigan leads the nation in production of highbush blueberry, comprising 33\% of the U.S. production. In Michigan in 2003 , there were 15,900 bearing acres of highbush blueberries producing 62 million $\mathrm{lb}$ (Kleweno and Matthews, 2004). Of this, 24 million lb were for the fresh market, receiving $\$ 1.30 / \mathrm{lb}$, and 38 million $\mathrm{lb}$ were for the processed food market, receiving $\$ 0.84 / \mathrm{lb}$. In the past 5 years in Michigan, farm gate value of the whole industry has ranged from \$49 (2001) to $\$ 63$ (2003) million (Kleweno and Matthews, 2004).

This industry has been challenged by the recent invasion of the japanese beetle into its major produc-

${ }^{1}$ USDA, ARS, PSI, Insect Biocontrol Laboratory, Bldg. 011A, Rm. 107, BARC-West, Beltsville, MD 20705.

${ }^{2}$ Department of Entomology, Michigan State University, 202 CIPS, East Lansing, MI 48824.

Acknowledgment is made to Dave Trinka and Gretchen Sonntag of Michigan Blueberry Growers Association, and Bob Tritten from MSU Genesee County Extension for assistance with this survey. Funding for this project was provided by Project GREEEN and by a North Central Region SARE graduate fellowship to Zsofia Szendrei. We thank all the Michigan blueberry growers who responded to this survey. This research was completed in partial fulfillment of the requirements for a doctoral degree in entomology at Michigan State University. tion centers. Although this pest was first detected in Michigan in 1932 (Michigan Department of Agriculture, 1962), populations of japanese beetle in western Michigan have increased in the past 10 years, and some growers are applying increasing amounts of insecticides to maintain beetle-free fruit. Japanese beetle adults start emerging in early July, and feed and mate on the bushes until mid-September, which coincides with the period of highbush blueberry harvest. Adult female japanese beetles lay eggs in grass-covered moist soil (Fleming, 1972; Potter and Held, 2002; Régnière et al., 1981), and many highbush blueberry growers manage grass (Poaceae) in row middles to suppress weeds and maintain soil quality. However, this provides ideal habitat for japanese beetle development (Szendrei et al., 2005). Conditions in and around crop fields can favor or inhibit survival and reproduction of japanese beetle depending on whether fundamental requirements for the pest population development are met (Vittum et al., 1999). Within many Michigan highbush blueberry fields and along the perimeter of these fields, a mix of different monocotyledonous and broadleaved weeds are commonly used to maintain soil structure, provide conditions where agricultural machinery can be driven during wet conditions, reduce soil erosion, and prevent pesticide and fertilizer runoff. These areas provide ideal conditions for japanese beetle where both the egg-laying and larval developmental requirements are met. Changing these parameters, as some growers are already doing, may reduce pest pressure over the long term by affecting the insect's biology.

The primary economic damage due to japanese beetles comes from the risk of contamination of harvested fruit and not from feeding damage. A majority of Michigan's highbush blueberries are sold for processing, and for this purpose fruit is harvested by machines that shake the highbush blueberries off the bushes. If japanese beetles are present on the fruit or foliage as the harvester passes over the bushes, there is a risk of japanese beetles being collected along with the highbush blueberries. Buyers require the harvested fruit to be completely free of insect contamination, and although postharvest techniques are available for removal of japanese beetles and other items from the fruit, this situation demands superlative pest control by the growers facing this pest in their fields. In 2001, japanese beetle was identified as the most important production problem for highbush blueberry by commercial growers in Michigan (North Carolina State University, 2001), and has become a major focus for research and extension programs.

This survey was developed in 2003 to collect information from commercial highbush blueberry growers in Michigan about the extent and magnitude of the challenge japanese beetles pose to highbush blueberry production. The survey was also conducted to quantify management tactics that growers have adopted to control japanese beetle and to determine the willingness of growers

\begin{tabular}{llll}
\hline $\begin{array}{l}\text { Units } \\
\begin{array}{l}\text { To convert U.S. to SI, } \\
\text { multiply by }\end{array}\end{array}$ & U.S. unit & SI unit & $\begin{array}{l}\text { To convert SI to U.S., } \\
\text { multiply by }\end{array}$ \\
\hline 0.4047 & $\mathrm{acre}(\mathrm{s})$ & $\mathrm{ha}$ & $2.471 \mathrm{l}$ \\
0.4536 & $\mathrm{lb}$ & $\mathrm{kg}$ & 2.2046
\end{tabular}


to incorporate alternative management strategies, such as the use of cover crops, in their future management programs if they are proven effective against japanese beetle.

\section{Materials and methods}

The survey was developed to cover both sides of a letter-size sheet of paper with 14 questions that could be quickly completed (about $15 \mathrm{~min}$ ). It was approved by the University Committee on Research Involving Human Subjects (UCRIHS) at Michigan State University prior to being mailed to commercial highbush blueberry growers in southern Michigan in 16 counties across the main highbush blueberry production regions of the state. Surveys were mailed to 215 growers in Winter 2003 by the Michigan Blueberry Growers' Association, Grand Junction, Mich., and by Genesee County Extension, Flint, Mich., who used their address lists to mail the surveys to growers. Reply envelopes with postage were enclosed with the surveys, and reminders to return surveys were made at Michigan State University Extension meetings in Dec. 2003. Each survey that was returned was given a unique identification number used for the data organization and analysis. Filling out the name and address fields was optional; thus the answers could remain anonymous, based on the decision of the respondent. Data were entered into spreadsheets (Excel, Windows 2000; Microsoft Corp., Redmond, Wash.) with the answers for each question entered on a separate sheet. Some growers had farms in multiple counties, and these were treated as separate entries for the analysis of the first three questions. This was the case for seven farms, and for these the total acreage was equally divided among the counties the farm was located in. Median and maximum values were calculated for values such as farm size and economic losses. Economic loss per acre was calculated by dividing the estimated loss peryear by the total acreage from each farm. The proportion of respondents answering questions in a certain way was calculated based on the number of respondents for each question. Answers were analyzed with a chi-square test to determine significant departures from those expected by chance (Kruskal-Wallis test; SAS Institute, Cary, N.C.).

\section{Results and discussion}

Surveys were received from commercial highbush blueberry growers in 16 counties of the southern tier of Michigan (Fig. 1A). A total of 99 surveys were returned, and these were used in the analyses. The median farm size throughout this study was 21 acres (range: 1-375 acres) (Fig. 1B).

Eighty-four percent of respondents considered japanese beetle a pest on their farms. On a $1-5$ scale, $(1=$ not important; 5 = extremely important), $31 \%$ found japanese beetle an extremely important production problem, a value significantly higher than expected $\left(\chi^{2}=11.52, P<0.05\right)$. Only $6 \%$ of the respondents thought it was not an important insect pest. Responses ranged between growers considering this pest to be the most important production problem on their farm, to those not having seen a japanese beetle.

Among the major highbush blueberry-producing counties (in southwestern Michigan), $53 \%$ of respondents considered japanese beetle as an extremely important production problem in Allegan County, whereas only $22 \%$ of respondents rated it this high in Muskegon County (Fig. 2). The reason that fewer growers consider japanese beetle an extremely important pest in Muskegon County could be because of its geographic location: it is in the northern part of the main highbush blueberry-growing region, and japanese beetles are not as abundant in the northern counties of Michigan as in the southern part of the state. This could be because the
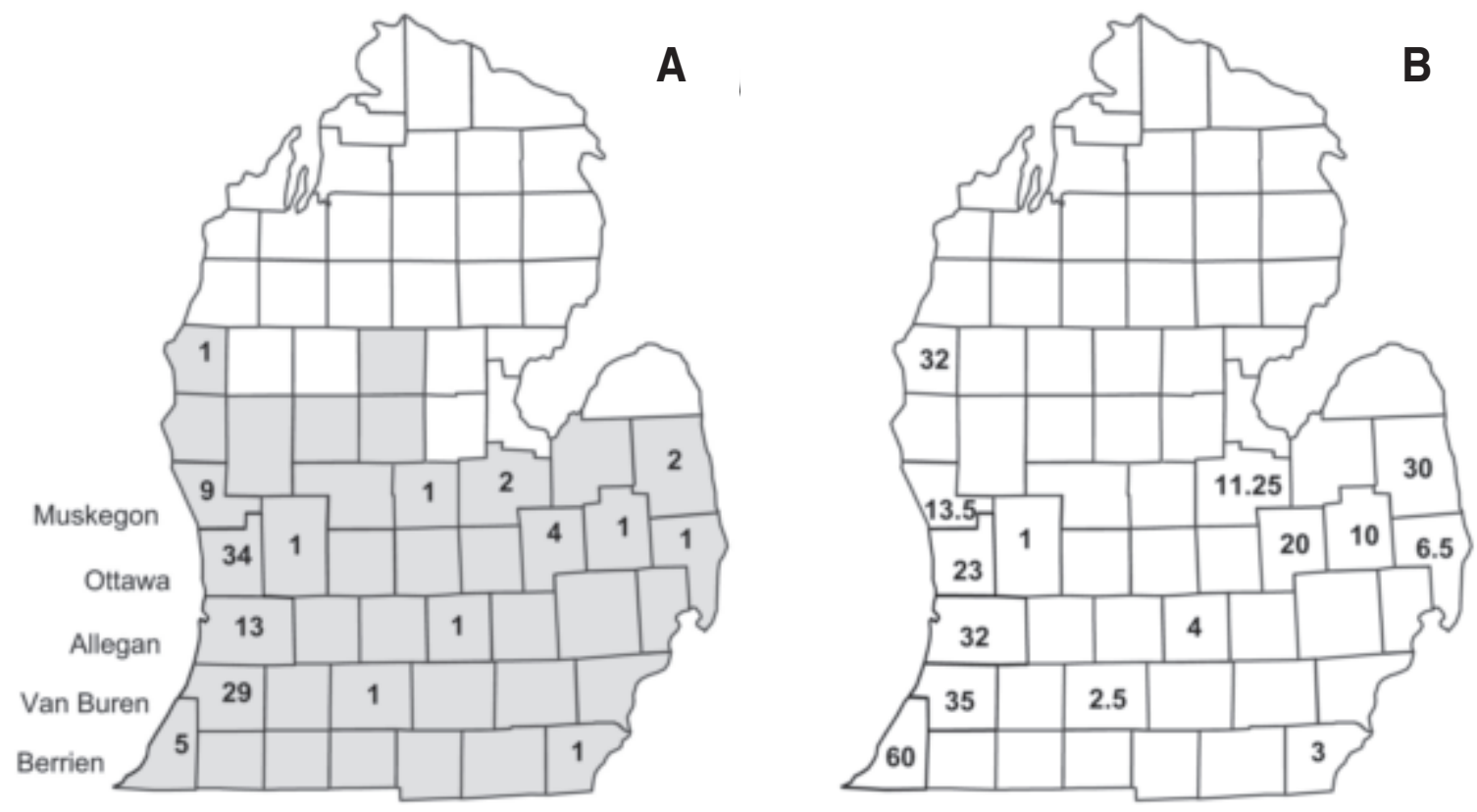

Fig. 1. Map of Michigan's lower peninsula with the number of responses (A) and median farm size (acres) (B) for the main highbush blueberry growing counties of Michigan. Names of the counties in the main highbush blueberry growing region are indicated on the left of map (A). Shaded areas on map (A) indicate approximate distribution of japanese beetle in Michigan (National Agricultural Pest Information System, 2005) (1 acre = 0.4047 ha). 
japanese beetle was first introduced into the state near Detroit (Michigan Department of Agriculture,1962), so it initially established in the southeast and/or because the climatic conditions in the northwestern part of the state are less suitable for sustaining japanese beetle populations (Fox, 1939).

The median economic loss due to japanese beetle as estimated by respondents was $\$ 72 /$ acre per year, and this value varied greatly among counties (overall range: \$10-\$1000/acre) (Fig. $3)$. In order to understand the causes of the ratings respondents gave to the magnitude of importance of japanese beetle as a pest, growers were asked about some of the production factors that might be responsible for this loss. More respondents were likely to consider japanese beetle a pest on their farm if they had overhead irrigation than if they did not: $64 \%$ of growers who ranked japanese beetle as an extremely or very important production problem have overhead irrigation $\left(\chi^{2}=\right.$ $124.19, P<0.05)$. More people rated japanese beetle a very or extremely important production problem who did not cultivate the soil around their fields $\left(76 \%, \chi^{2}=5.38, P<0.05\right)$, than if they cultivated the soil around their fields $(23 \%)$.

Seventy-nine responses were received to the question investigating the reason for the economic loss due to japanese beetle. Significantly more than expected $\left(63 \%, \chi^{2}=67.12, P<\right.$ $0.05)$ of the respondents indicated increased insecticide use as the major reason (Fig. 4). According to others, the damaged fruit reduced product value; damaged bushes had lower yield than undamaged bushes; there was an increased need for cultivation; harvest time was prolonged; or more labor and time were needed to remove japanese beetles from harvested fruit. The risk of load rejection was considered to be a reason for increased cost by only $11 \%$ of growers, perhaps because if this occurs, it would be after the fruit have left the farm.

The two most widely used methods of japanese beetle control were foliar insecticides $(63 \%)$ and clean cultivation (16\%) (Fig. 5). The other methods listed were used by fewer than $21 \%$ of respondents. These include herbicide-killed sod, cover crops, and the use of soil insecticides. Four growers used traps to reduce the number of japanese beetles (although this strategy

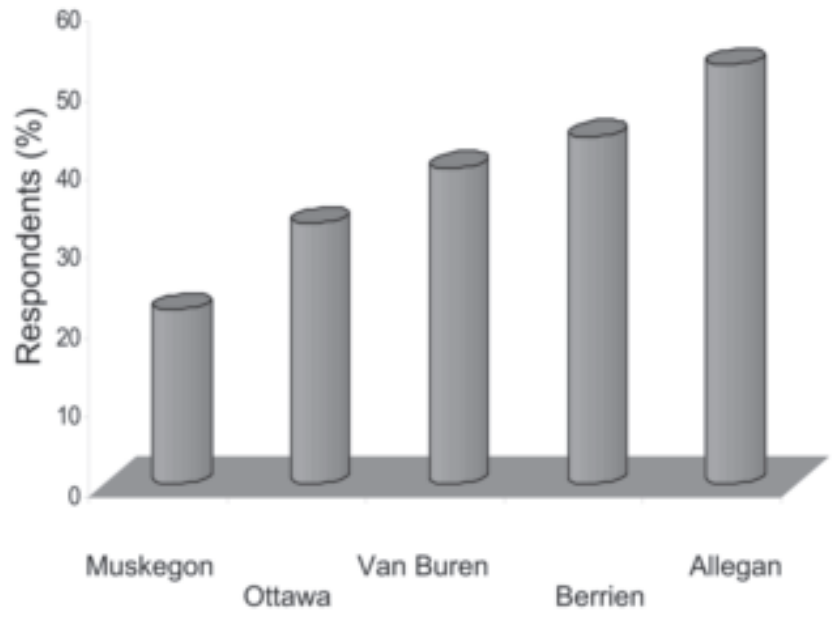

Fig. 2. Percentage of growers' responses ranking japanese beetle as the most important pest in highbush blueberry production, in the main highbush blueberry-growing counties in Michigan.

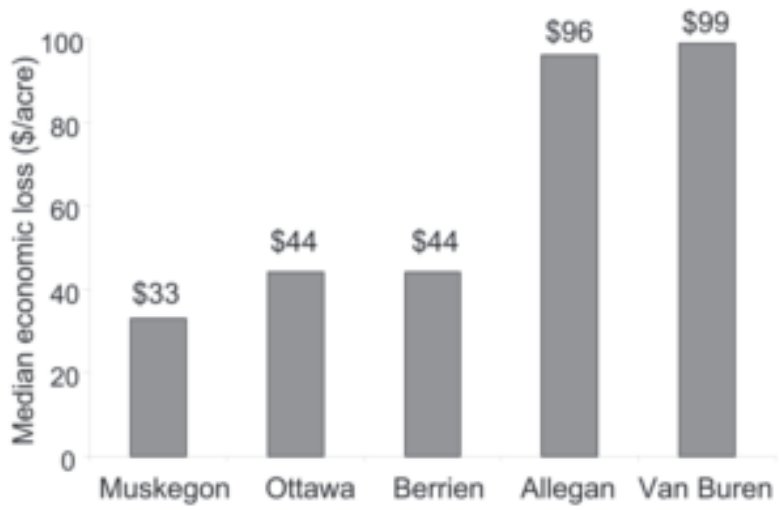

Fig. 3. Estimated economic loss per acre from japanese beetle at highbush blueberry farms in southwestern Michigan counties $(\$ 1.00 /$ acre $=\$ 2.4711 / \mathrm{ha})$.

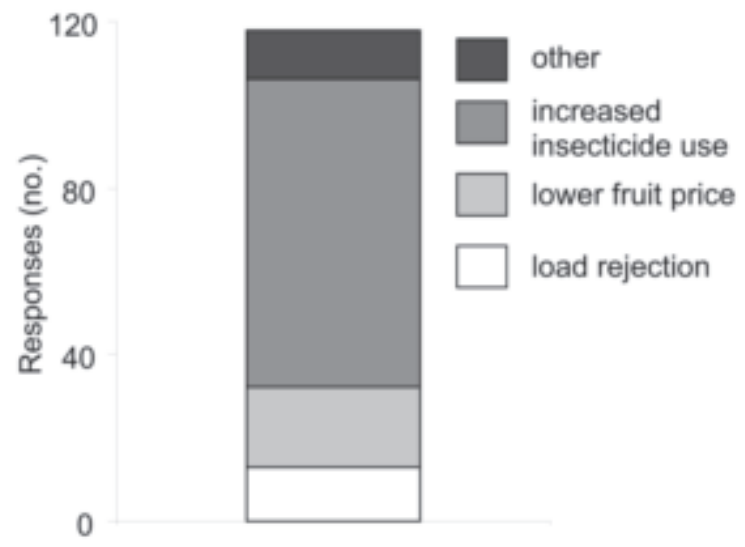

Fig. 4. Responses of highbush blueberry growers involved in the survey about the potential causes of the economic impact due to japanese beetle.

could potentially attract more japanese beetles into the crop), while others (six responses) removed from the field non-crop plants that attract japanese beetle. These results show that growers rely heavily on foliar insecticides for their japanese beetle control, but that they are adopting additional approaches to help reduce the incidence of this pest.

Eighty-five of the respondents answered the question about the type of groundcover used at their farm. Thirty-one out of the 85 respondents 
(37\%) had permanent sod throughout the row middles across their farms (Fig. 6A). The second most commonly used row-middle treatment was clean cultivation. Only 24\% of the growers who answered the question had their entire farm clean-cultivated, but nearly twice as many acres were clean-cultivated (2067 acres) as were kept with permanent sod (1254 acres) (Fig. 6B). Only $15 \%$ of the 85 answers indicated the use of multiple groundcovers at an individual farm. Of the growers that replied to the survey, there were 544 acres of farms with herbicide-killed sod, and 207 acres of other types of groundcovers. These included rye ( $\mathrm{Se}$ cale cereale) and herbicide-killed rye.

We asked whether growers had changed row-middle management practices to control japanese beetle. Ninety-two responses were received to the question and $42 \%$ of these growers changed row-middle management practices, with their changes starting on average in 2000. Of 38 growers who changed management methods, 27 switched to clean cultivation and eight changed to herbicide-killed sod. In one case the grower started narrowing the sod strip in row middles, and in another the grower switched to mowing more often. This clearly shows a tendency to move away from living row-middle groundcovers. Fifty percent of growers who had made a change said that the changes reduced japanese beetle pressure, and $45 \%$ were not sure. When asked whether they would be willing to incorporate new cover crops into their management strategies to control Japanese beetle if they were effective, $59 \%$ of the 90 respondents answered "yes" (Fig. 7), indicating a potential for integrating alternative groundcovers into Michigan highbush blueberry fields.

Eighty-nine responses were received to the questions about the perceived advantages and disadvantages of cover crops and clean cultivation in highbush blueberry fields (Table 1). The two most important advantages of cover crops, according to growers, were prevention of soil erosion $(65 \%$, $\left.\chi^{2}=34.5, P<0.05\right)$ and preservation of soil moisture $\left(42 \%, \chi^{2}=16.0, P\right.$ $<0.05)$. The most important disadvantage of having cover crops was that they compete with the highbush blueberry bushes (44\%, nonsignificant) and they might serve as an alternative host for pests $(40 \%$, nonsignificant ).

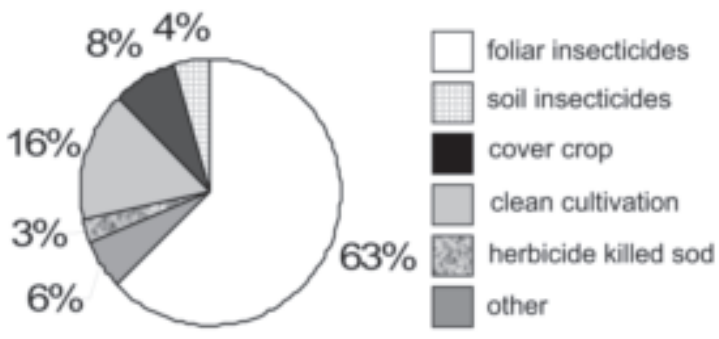

Fig. 5. Proportion of Michigan highbush blueberry growers' responses to the question, "What is the most important japanese beetle control method?"

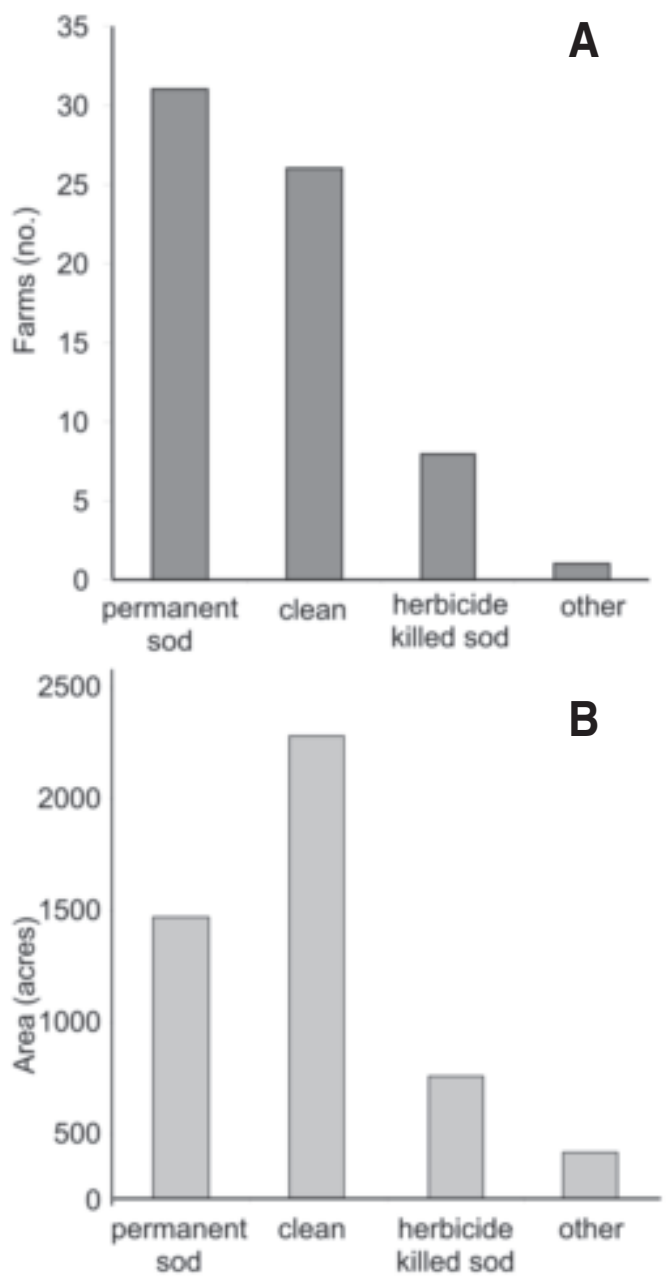

Fig. 6. The number (A) and total acreage (B) of Michigan highbush blueberry farms with different types of row-middle management as shown by growers' responses to the survey $(1$ acre $=0.4047 \mathrm{ha})$.

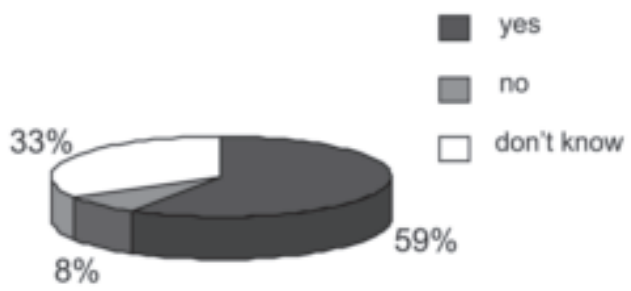

Fig. 7. Answers of highbush blueberry growers in Michigan to the survey question, "Would you be interested in using new groundcovers if they were effective against japanese beetle?" 
Seventy-six percent ( 68 answers out of 89 ) of the growers answered that having clean cultivation provides control of pests $\left(\chi^{2}=31.1, P<0.05\right)$, and half as many answers (34) indicated that clean cultivation is advantageous because it decreases frost damage in the fields. The main disadvantage of clean cultivation, according to the survey, was that it creates muddy and dusty conditions $\left(\chi^{2}=16.1, P<0.05\right)$, and the second disadvantage of clean cultivation was that it facilitates soil erosion. Interestingly, increased cost, such as the expense of cover crop seeds or cultivation (as opposed to maintaining row middles with cover crop) was never considered of high importance. Growers' answers indicated that the issues they consider when deciding what soil management method to apply in their fields are mostly horticultural, based on the effect on bushes (competition of cover crops for soil moisture) and insect pests (cover crops could provide alternate hosts for pests, and clean cultivation is a method of pest control). Complaints about mud, dust, and erosion in highbush blueberry fields are common among growers who have clean cultivation (Z. Szendrei, personal communication with growers), and most of the highbush blueberry fields in western Michigan have light, sandy soils that are prone to erosion and create dust when dry.

Seventy-two percent of respondents did not cultivate the soil around their fields. Growers maintain this area to have permanent sod cover in the driveways and around the fields for the maneuverability of tractors and harvesters. These areas therefore cannot be switched to clean cultivation, and there is a need to develop effective approaches to control japanese beetle grubs that are developing in this area of the farms (Szendrei et al., 2005).

We asked growers if there were any changes to their current japanese beetle programs that they were planning for the future. Twenty-two out of $73(30 \%)$ answered "yes." The types of changes growers were planning included: switching to clean cultivation, planting cover crops, applying herbicide to row middles, use more foliar insecticides, removing weeds, spraying the field perimeters, or using soil insecticides. One grower was planning on planting grapes around the field as a trap crop and spraying them with insecticide (although this may not

Table 1. Advantages and disadvantages of cover crops and clean cultivation for integration into highbush blueberry production, and the percentage of survey respondents that consider these important (in order of importance). Eighty-nine responses were given.

\begin{tabular}{lccc}
\hline Advantages & $\begin{array}{c}\text { Response } \\
(\mathbf{\%})\end{array}$ & \multicolumn{1}{c}{ Disadvantages } & $\begin{array}{c}\text { Response } \\
\text { (\%) }\end{array}$ \\
\hline & \multicolumn{3}{c}{ Cover Crop } \\
1. Prevents soil erosion & 65 & 1. Competition with bushes & 44 \\
2. Conserves soil moisture & 42 & 2. Alternative host for pests & 41 \\
3. Controls pests & 36 & 3. Too expensive & 30 \\
4. Cuts fertilizer costs & 12 & 4. Difficult to seed & 21 \\
& Clean cultivation & 76 \\
1. Controls pests & 76 & 1. Mud and dust in field & 54 \\
2. Decreases frost damage & 38 & 2. Soil erosion & 34 \\
3. Easy to manage & 30 & 3. Soil moisture loss & 25 \\
4. Low cost of maintenance & 12 & 4. Need for herbicides & 25 \\
\hline
\end{tabular}

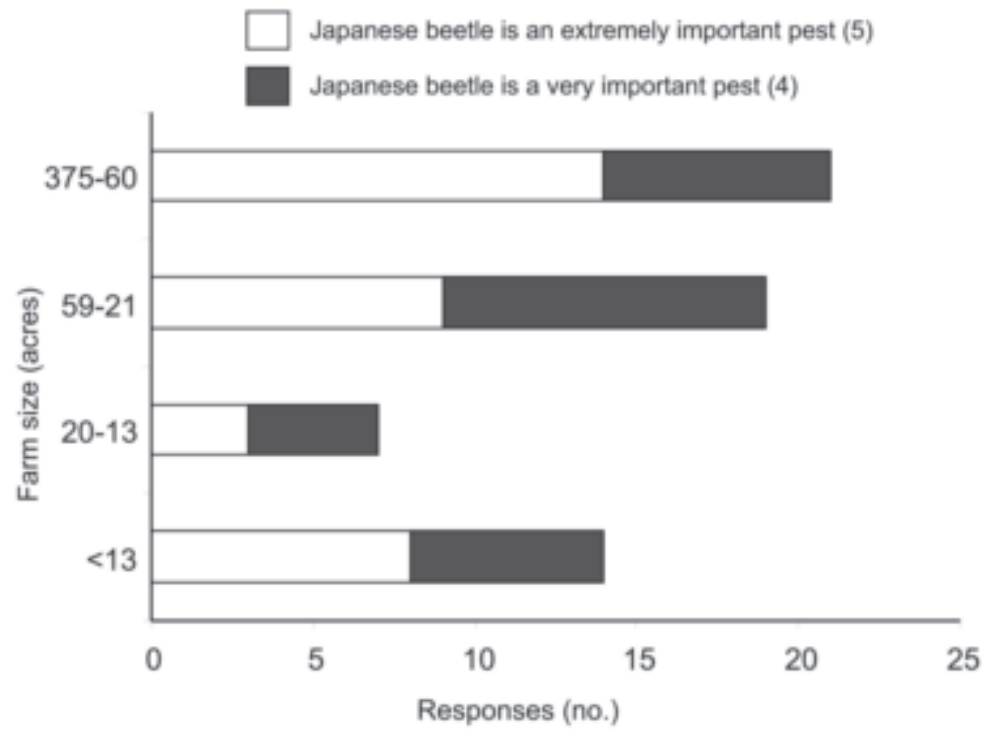

Fig. 8. The relationship between highbush blueberry farms size and the importance of japanese beetles as pest in highbush blueberry production in Michigan. Importance of the pest was on a scale from 1 (not important) to 5 (extremely important); results shown in the graph are ranks 4 and 5 only ( 1 acre $=0.4047$ ha).

be beneficial, because of the potential for attracting japanese beetles to the area of the field). Thirteen out of the 30 respondents who said that japanese beetle was an extremely important pest on their farm would not change their current management program. Twelve said they would change their management program, and the most common form of change was to spray more foliar insecticide.

Seventy-two answers were received to the question about whether there are other equally or more important pest management problems besides japanese beetle. Blueberry maggot (Rhagoletis mendax) was the most common other pest problem for growers $(23 \%)$, but other common answers were cranberry fruitworm (Acrobasis vaccinii) (17\%), diseases (9\%), weeds $(7 \%)$, birds $(6 \%)$, mammals [woodchuck (Marmota monax) and white-tailed deer (Odocoileus virginianus), 6\%]. There were a few sporadic problems with other insect pests mentioned, which included rosechafer beetle (Macrodactylus subspinosus), tussock moths (Orgyia leucostigma), blueberry gall wasp (Hemadas nubilipennis), blueberry aphids (Illinoia pepperi), and oblique banded leafrollers (Choristoneura rosaceana). One grower said that government regulations were an equally or more important problem than japanese beetle.

Among the growers who listed japanese beetle as an extremely im- 
portant pest on their farm, cranberry fruitworm and blueberry maggot were the most common other production problems, while weeds and cherry fruitworm (Grapholita packardi) were the second most common responses.

When comparing farm size and the importance of japanese beetle in production we found that $67 \%$ of the owners of large farms (60-375 acres) said that japanese beetle is an extremely important pest on their farm, $43 \%$ of the 13-20 acre and $53 \%$ of the less than 13-acre farm owners said the same (Fig. 8). Twice as many large farm owners gave rank 5 (extremely important pest) rather than rank 4 (very important pest), whereas this difference was only 1.3-fold in the case of small farm owners ( $<13$ acres). The reason for this might be that most of the larger farms are located in the southwestern part of the state, where japanese beetle pest pressure is high. This result could mean that growers who could potentially suffer a large economic loss due to japanese beetle are more aware of the importance of this pest or because more japanese beetles are attracted to a large field of highbush blueberries than a small one, or that the pest management program is easier to manage on a smaller farm than on a large one, particularly around harvest time.

\section{Conclusion}

This grower survey shows that japanese beetle is an important pest management challenge for highbush blueberry producers in southern Michigan, with significant economic impact. Due to this pest, increased insecticide use was the major cause of the economic loss for producers. The most widely used methods of controlling japanese beetle in Michigan highbush blueberry fields are insecticides and clean cultivation. Szendrei et al. (2005) showed that clean-cultivated fields had fewer japanese beetle larvae than fields with permanent sod. In Michigan highbush blueberry fields, more farms have permanent sod cov- erage than clean cultivation, but the acreage of clean-cultivated farms is higher. This means that larger farms tend to be clean-cultivated, which could be correlated with the risk factor and amount of economic loss a grower could suffer if a japanese beetle was detected in the harvested fruit. It is likely that this trend is because growers who have larger farms and rely on highbush blueberry farming for income are taking more precautions to minimize the chance of contamination of fruit with japanese beetle. Up until recently, japanese beetle has been driving changes in row-middle management, as indicated by growers recently switching to clean cultivation. The changes implemented to control japanese beetle are considered to be effective by growers responding to this type of survey, and most growers (70\% of respondents) are not planning on making more changes to their pest management programs. Many growers would be willing to try new cover crops if they are shown to be effective against this pest.

This type of survey is important because the results point out a number of further opportunities for research and extension toward the adoption of new strategies to control japanese beetle in highbush blueberry. The information gathered here could be used to develop control strategies that rely on realistic management needs and existing methods. Usefulness of grower surveys in developing future research directions has also been found in the case of strawberry (Fragaria $\times$ ananassa) growers in Ohio (Scheerens and Brenneman, 1990) and New York (Stivers-Young and Tucker, 1999). In the latter survey, the authors identified the types of cover crops that were currently being planted and the advantages and disadvantages that growers perceived when using them. In the future, participatory research that actively includes growers may speed up appropriate adoption of new cover crops or other strategies to help control japanese beetle and other pests.

\section{Literature cited}

Fleming, W.E. 1972. Biology of the japanese beetle. USDA Tech. Bul. No. 1449, U.S. Govt. Printing Office, Washington, D.C.

Fox, H. 1939. The probable future distribution of the japanese beetle in North America. J. New York Entomol. Soc. 47:105-123.

Kleweno, D.D. and V. Matthews. 2004. Michigan agricultural statistics 2003-2004. Michigan Department of Agriculture 2003 annual report. Michigan Dept. of Agr. and USDA, Natl. Agr. Stat. Serv. Michigan Agr. Stat., Lansing.

Michigan Department of Agriculture. 1962. Japanese beetle control program. Annual report for 1962. Michigan Dept. Agr., Detroit.

National Agricultural Pest Information System. 2005. Japanese beetle distribution in the continental USA and Puerto Rico. 2004. 22 Sept. 2005. <http:/www. ceris.purdue.edu/napis/pests/jb/imap/ jb2004html>.

North Carolina State University. 2001. Pest management strategic plan for the Michigan blueberry industry. 20 Sept. 2005 <http://pestdata.ncsu.edu/pmsp/ pdf/MIblueberry.pdf>.

Potter, D.A. and D.W. Held, 2002. Biology and management of the japanese beetle. Annu. Rev. Entomol. 47:175-205.

Régnière, J., R.L. Rabb, and R.E. Stinner. 1981. Popillia japonica: Effect of soil moisture and texture on survival and development of eggs and first instar grubs. Environ. Entomol. 10:654-660.

Scheerens, J.C., and G.L. Brenneman. 1990. Survey of Ohio strawberry growers: Present practice and future directions. Res. Circ.-Ohio Agr. Res. Dev. Ctr. 297:39-49.

Stivers-Young, L.J. and F.A. Tucker. 1999. Cover-cropping practices of vegetable producers in western New York. HortTechnology 9:459-465.

Szendrei, Z., N. Mallampalli, and R. Isaacs. 2005. Effect of cultivation on abundance of japanese beetle, Popillia japonica Newman (Coleoptera: Scarabaeidae), in highbush blueberry fields. J. Appl. Entomol. 129:258-264.

Vittum, P.J., M.G. Villani, and H. Tashiro. 1999. Turfgrass insects of the United States and Canada. 2nd ed. Cornell Univ. Press, Ithaca, N.Y. 